\title{
Inferring mating system parameters in forage peanut, Arachis pintoi, for Brazilian Amazon conditions
}

\author{
Jônatas Chagas de OLIVEIRA ${ }^{1}$ ๑, Polinar Bandeira RUFINO², Hellen Sandra Freires da Silva AZÊVEDO ${ }^{3}$, \\ Adna Cristina Barbosa de SOUSA ${ }^{4}$, Giselle Mariano Lessa de ASSIS ${ }^{5}$, Lucielio Manoel da SILVA 5 , \\ Alexandre Magno SEBBENN ${ }^{6}$, Tatiana de CAMPOS ${ }^{5 *}$

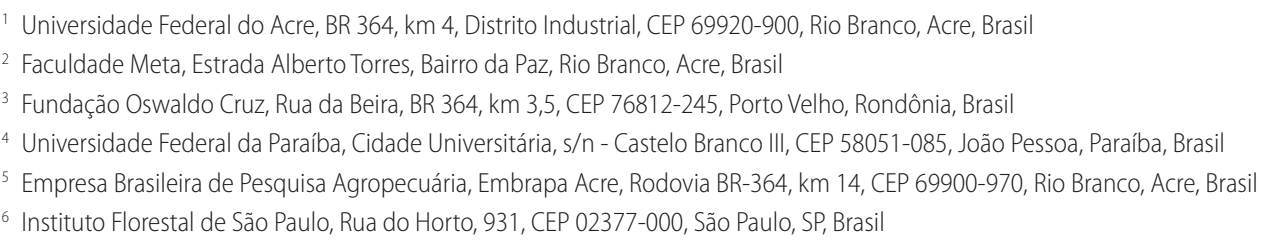

\section{ABSTRACT}

The search for alternatives to increase productivity and sustainability of livestock production in the Amazon region without increasing deforestation is challenging. Mixed pastures of grasses with forage peanut (Arachis pintoi) have shown positive economic impacts. However, gaps in the knowledge of the reproductive biology of $A$. pinto $i$ have limited the development of new cultivars adapted to the environmental variations in the Brazilian Amazon. Pasture consortiums of Brachiaria humidicola with forage peanuts (cv. Mandobi) resulted in a $42 \%$ increase in weight gain productivity. New cultivars better adapted to the Amazon climate should bring even greater gains. We evaluated the mating system in twenty A. pintoi accessions, and approximately 40 offspring per accession genotyped with eight microsatellites (or markers). The parameters of genetic diversity and inbreeding, the outcrossing rate and coancestry were calculated. The observed heterozygosity was significantly higher and the fixation index was significantly lower in adults compared with the offspring. The crossing rate was variable among genotypes (2 to $80 \%$ ), and the mean outcrossing rate was $36 \%$. These results indicate that pollinator presence in pastures can influence gene flow in A. pintoi more than expected. Arachis pintoi presented a mixed mating system with a predominance of selfing, and families presented inbreeding and different levels of relatedness. New strategies of genotype conservation are needed to avoid pollinator-mediated crossing between accessions.

KEYWORDS: reproductive system, Arachis pintoi, SSR, crossing rate

\section{Inferindo parâmetros do sistema de cruzamento em amendoim forrageiro, Arachis pintoi, para as condições da Amazônia brasileira}

\section{RESUMO}

A busca por alternativas para aumentar a produtividade e a sustentabilidade da pecuária na região Amazônica sem aumentar o desmatamento é desafiadora. Pastagens consorciadas de gramíneas com amendoim forrageiro (Arachis pintoi) têm mostrado impactos econômicos positivos. Porém, lacunas no conhecimento da biologia reprodutiva do amendoim forrageiro tem limitado o desenvolvimento de novas cultivares adaptadas as variaçôes ambientais na Amazônia brasileira. Pastos consorciados de Brachiaria humidicola com amendoim forrageiro (cv. Mandobi) apresentaram cerca de $42 \%$ de aumento na produtividade do ganho de peso. Novas cultivares mais adaptadas ao clima amazônico, poderão trazer ganhos ainda maiores. O objetivo desse estudo foi avaliar o sistema reprodutivo em vinte acessos de $A$. pinto $i$ e aproximadamente 40 progênies por acesso, genotipadas com oito microssatélites (ou marcadores). Os parâmetros de diversidade genética e endogamia, taxa de cruzamento e coancestria foram calculados. A heterozigosidade observada foi significativamente maior e o índice de fixação foi significativamente menor nos adultos comparado às progênies. A taxa de cruzamento foi variável entre os genótipos ( 2 a $80 \%)$ e a média da taxa de cruzamento foi $36 \%$. Esses resultados indicam que a presença de polinizadores em pastagens pode influenciar o fluxo gênico em $A$. pintoi mais do que o esperado. Arachis pintoi apresentou um sistema de cruzamento misto com predominância de autofecundação e as famílias apresentaram endogamia e diferentes níveis de parentesco. Novas estratégias de conservação de genótipos são necessárias para evitar polinizadores mediadores de cruzamento entre os acessos.

PalaVRaS-ChaVE: sistema reprodutivo, Arachis pintoi, SSR, taxa de cruzamento 


\section{INTRODUCTION}

Brazil has the second largest cattle herd in the world, with $39 \%$ of the cattle population located in the legal Amazon (the region comprising the Brazilian states of Acre, Amapá, Pará, Amazonas, Rondônia, Roraima, Mato Grosso, Tocantins and Maranhão), which makes livestock farming an important economic activity in the region (Ferraz and Felício 2010; IBGE 2017). However, the growing demand for sustainable livestock production and reduction of deforestation in the Amazon presents a number of challenges (Dias Filho 2011; Mazzetto et al. 2015; Zu Ermgassen et al. 2018). Among the alternatives for sustainable livestock production, the use of mixed pastures of grasses with forage peanuts (Arachis pinto $i$ Krapov and W.C. Greg.) has generated positive results, with an economic impact of R\$104 million (US\$ 27 million) in the state of Acre (Embrapa 2018), due to a $42 \%$ increase in weight gain per animal compared to grass-only pastures (Urbanski 2016). Mixed pastures also contribute to soil fertility through biological nitrogen fixation, promoting the recovery of degraded areas (Barcellos et al. 2008; Garcia et al. 2017; $\mathrm{Zu}$ Ermgassen et al. 2018). Despite these advantages, few forage peanut cultivars are commercially available. Therefore, the development of new cultivars adapted to regional environmental conditions is of great importance (Simeão et al. 2017), and requires knowledge on the reproductive biology of forage peanut. The mating system of $A$. pinto $i$ has not been investigated in terms of outcrossing, mating among related individuals and correlated mating. Most wild species of Arachis exhibit a floral biology that favors self-fertilization, given that their flowers are hermaphrodites that exhibit selfpollination (Krapovickas and Gregory 2007). However, crosspollination can occur through the action of pollinator vectors, such as bees of the genus Centris, Trigona, Megachile and Apis mellifera (Drumond and Cardoso 2010). Mating system studies in Arachis are limited to A. hypogaea and are based on morphological markers, revealing a low outcrossing rate that ranged from 1.9 to $8 \%$ (Coffelt 1989; Knauft et al. 1992). Oliveira and Valls (2003) also used morphological markers to evaluate the reproductive system in five accessions of $A$. pinto $i$ and two of $A$. repens. They detected the presence of autogamy and self-incompatibility in $A$.pinto $i$, and allogamy in $A$. repens accessions. Mating system studies based on markers, such as microsatellite loci or simple sequence repeats (SSR), allow the determination of the outcrossing rate, mating among relative individuals and correlated mating, as well as the levels of genetic diversity, inbreeding and relatedness within families (Degen and Sebbenn 2014). Therefore, the main aim of this study was to quantify rates of outcrossing, mating among relative individuals and correlated mating in $A$. pinto $i$ using microsatellite markers. We also evaluated the relatedness among plants of an active germplasm bank (AGB) located at Embrapa Acre, which has 139 accesses and is a basis of the forage peanut breeding program.

\section{MATERIAL AND METHODS}

\section{Plant material}

The study was performed using 20 accessions (V 6727, cv. Alqueire, V 14951, V 13330, V 6741, V 6784, W 34, W 647, V 5895, V 6740, V 13196, V 13198, V 6791wf, cv. Belomonte, Sv 8311, W 1000, cv. Mandobi, cv. Amarillo MG-100, V 13888, and W 34B) of $A$. pintoi from the AGB at Embrapa Acre, Acre state, Brazil. The matrices represent the commercial cultivars available in Brazil and the higher seed producers in the AGB. The 20 matrices were planted by stolon in vessels of $1.0 \times 0.9 \mathrm{~m}$ in December 2012. The vessels were placed in an open field about $3 \mathrm{~m}$ distant from the AGB. Considering the variable maturation period required to obtain sufficient seed numbers per matrix, seeds were collected twice, eight and 15 months after the matrices were planted. To obtain a minimum of 35 offspring per matrix, approximately 60 seeds per matrix were submitted to a breaking dormancy process (Assis et al. 2015) and were planted in sterile sand.

\section{DNA extraction and SSR genotyping}

DNA extraction, agarose quantification and assessment of eight microsatellites loci (Ah07, Ah11, Ah21, Ag39, Ag140, Ap40, Ap175, and Ap176) (Palmieri et al. 2002; Hoshino et al. 2006; Gimenes et al. 2007) were performed as described by Campos et al. (2016). Amplification reaction and genotyping were performed according to Azêvedo et al. (2017).

\section{Statistical analysis}

The genotypic disequilibrium between a pair of loci was calculated for the matrices. The statistical significance was tested using 1,000 permutations of alleles among individuals and subjected to a Bonferroni correction for multiple tests (95\%, $\alpha=0.05)$. For matrices and offspring, genetic diversity was characterized as a mean between all loci using the following indices: total number of alleles per loci $(k)$, allelic richness $(R)$ estimated using rarefaction, observed $\left(H_{o}\right)$ and expected heterozygosity $\left(H_{e}\right)$ under Hardy-Weinberg equilibrium. Inbreeding in the samples was estimated using the population fixation index $(F)$. Statistical significance of $\mathrm{F}$ values was tested by 1,000 permutations of alleles among individuals and subjected to a Bonferroni correction for multiple tests (95\%, $\alpha=0.05)$. All estimates were calculated using FSTAT software (Goudet 1995). The un-paired t-test was used to evaluate whether the indices of genetic diversity and inbreeding were significantly different between samples. The relatedness between pairwise matrices was estimated using the coancestry coefficient and Spagedi 1.3 software (Hardy and Vekemans 2002). We classified pairwise individuals as related groups, assuming related individuals if pairwise values were at least 0.05 .

Mating system indices were estimated at the population and individual levels based on a mixed mating system and correlated mating model using the Expectation-Maximization 
(EM) numerical method implemented in MLTR 3.4 software (Ritland 2002). The following indices were calculated at individual and population levels: the fixation index of matrices $\left(F_{m}\right)$, multilocus outcrossing rate $\left(t_{m}\right)$, single-locus outcrossing rate $\left(t_{s}\right)$, rate of mating among relative individuals $\left(t_{m}-t_{s}\right)$, and multilocus paternity correlation $\left(r_{p(m)}\right)$. At the population level, we also estimated the correlation of $t$ between families $\left(r_{t}\right)$ and correlation of $t$ between loci $\left(r_{l}\right)$. The standard error of the indices was estimated by 1,000 bootstrap resampling within families. We also estimated the effective number of pollen donors $\left(\mathrm{N}_{\mathrm{ep}}=1 / r_{p}\right)$ and the average coancestry coefficient within families: $\Theta=0.125\left(1+F_{m}\right)\left[4 s+t_{m}{ }^{2}\left(1+r_{p}\right)\right]$, where $F_{m}$ is the inbreeding coefficient in matrices and $s$ is the selfing rate $(s=$ $\left.1-t_{m}\right)$ (Sebbenn 2006). The effective size $\left(N_{e}\right)$ within families was estimated from sample variance in the gene frequency as described by Tambarussi et al. (2015) and Wadt et al. (2015).

\section{RESULTS}

\section{Genetic diversity}

Of the 20 matrices, only 12 produced more than the minimum number established of 35 seeds. From 35 to 56 offspring per matrix were obtained for genotyping for a total of 531 individuals (Table 1).

The eight analyzed loci were polymorphic. The number of alleles per loci for the total samples of adults and offspring ranged from five to 19 , totaling 83 different alleles. After the

Table 1. Genetic diversity and inbreeding for matrices and offspring of forage peanut, Arachis pintoi accesses. $P_{\text {value }}=$ probability of un-paired t-test.

\begin{tabular}{lccc}
\hline Index & Matrices & Offspring & $P_{\text {value }}$ \\
\hline Sample size: $n$ & 12 & 531 & - \\
\hline Total number of alleles: $k$ (range) & $61(4-13)$ & $83(5-19)$ & - \\
Allelic richness for 12 genotypes: $R$ & 7.6 & 6.4 & 0.153 \\
Observed heterozygosity: $H_{0}$ & 0.83 & 0.50 & $<0.001$ \\
Expected heterozygosity: $H_{e}$ & 0.78 & 0.73 & 0.312 \\
Fixation index: $F$ & -0.07 & 0.31 & $<0.001$ \\
\hline
\end{tabular}

Bonferroni correction, no genotypic disequilibrium between pairwise loci was detected for the matrices sampled. According to the t-test, the observed heterozygosity $\left(H_{o}\right)$ was significantly higher in matrices (0.83) as compared with offspring $(0.50)$, whereas the expected heterozygosity $\left(H_{e}\right)$ was not significantly different between matrices (0.78) and offspring (0.73). The fixation index $(F)$ was significantly lower in matrices $(-0.07)$ as compared with offspring $(0.31)$, and the value for offspring was greater than zero, indicating inbreeding.

\section{Relatedness among accessions}

Pairwise coancestry coefficients between matrices ranged from -0.162 to 0.211 and were negative in $56 \%$ of the 66 estimates, indicating the absence of relatedness in this case (Table 2). This finding confirmed the genetic diversity observed among the genotypes. Comparing pairwise estimates, and assuming related individuals if pairwise values were at least 0.05 , four probable groups of related individuals were detected with coancestry ranging from 0.050 to 0.211 . The groups were i) genotypes V 13196, V 13198, W 1000 and V 5895 with pairwise coancestry ranging from 0.050 to 0.190 ; ii) $\mathrm{V} 6727$ and V 6784 with pairwise coancestry of 0.127 ; iii) V 6740, V 6791wf and Amarillo MG-100 with pairwise coancestry ranging from 0.124 to 0.211 ; iv) W 34, W 647 and V 13888 with pairwise coancestry ranging from 0.089 to 0.211 .

\section{Mating system}

Multilocus outcrossing rate $\left(t_{m}\right)$ was highly variable among families, ranging from 0.02 to 0.80 with a general rate of $t_{m}=$ 0.36 (Table 3). The correlation of $t$ among families $\left(r_{t}=0.43\right.$, $\mathrm{SE}=0.04)$ indicated high variation in outcrossing rate among matrices. The correlation of $t$ between the loci $\left(r_{l}=0.52\right.$, SE $=0.04)$ indicated that inbreeding in offspring originated from approximately $50 \%$ self-fertilization and $50 \%$ mating among related individuals. The rate of mating among related individuals $\left(t_{m}-t_{s}\right)$ and the paternity correlation $\left(r_{p(m)}\right)$ were also variable among matrices $\left(t_{m}-t_{s}:-0.24-0.37 ; r_{p(m)}: 0.10\right.$

Table 2. Pairwise coancestry coefficient between accessions of forage peanut, Arachis pintoi.

\begin{tabular}{|c|c|c|c|c|c|c|c|c|c|c|c|}
\hline & V6727 & V6784 & W34 & W647 & V5895 & V6740 & V13196 & V13198 & V6791wf & W1000 & Amarillo MG-100 \\
\hline V6784 & 0.127 & & & & & & & & & & \\
\hline W34 & 0.075 & -0.033 & & & & & & & & & \\
\hline W647 & 0.036 & -0.071 & 0.127 & & & & & & & & \\
\hline V5895 & -0.159 & -0.016 & -0.026 & -0.023 & & & & & & & \\
\hline V6740 & -0.016 & 0.002 & -0.051 & 0.036 & -0.075 & & & & & & \\
\hline V13196 & 0.009 & 0.068 & -0.110 & -0.064 & 0.159 & -0.033 & & & & & \\
\hline V13198 & -0.044 & 0.057 & -0.162 & -0.075 & 0.106 & -0.044 & 0.190 & & & & \\
\hline V6791wf & 0.040 & 0.016 & -0.037 & 0.050 & -0.061 & 0.124 & -0.145 & -0.071 & & & \\
\hline W1000 & -0.016 & -0.040 & -0.009 & -0.047 & 0.050 & -0.058 & 0.134 & 0.165 & -0.044 & & \\
\hline Amarillo MG-100 & 0.029 & 0.005 & -0.047 & 0.040 & -0.071 & 0.197 & -0.071 & -0.082 & 0.211 & -0.054 & \\
\hline V13888 & -0.131 & -0.113 & 0.211 & 0.089 & 0.103 & 0.036 & -0.064 & -0.033 & 0.009 & -0.047 & -0.044 \\
\hline
\end{tabular}


Table 3. Estimates of individual and population mating system indices in forage peanut, Arachis pintoi. $n=$ sample size; $t_{m}=$ multilocus outcrossing rate; $t_{s}=$ single locus outcrossing rate; $t_{m}-t_{s}=$ rate of mating among related individuals; $r_{p(m)}=$ multilocus paternity correlation; $N_{e p}=$ effective number of pollen donors; $\Theta=$ coancestry coefficient within family; $N_{e}=$ effective size; (SE) = standard error.

\begin{tabular}{lcccccccc}
\hline Matrix & $n$ & $t_{m}(\mathrm{SE})$ & $t_{s}(\mathrm{SE})$ & $t_{m}-t_{s}(\mathrm{SE})$ & $r_{p(m)}(\mathrm{SE})$ & $N_{e p}$ & $\Theta$ & $N_{e}$ \\
\hline V6727 & 42 & $0.70(0.07)$ & $0.33(0.02)$ & $0.37(0.05)$ & $0.86(0.02)$ & 1.2 & 0.264 & 1.86 \\
V6784 & 41 & $0.62(0.08)$ & $0.52(0.06)$ & $0.10(0.05)$ & $0.19(0.05)$ & 5.2 & 0.249 & 1.96 \\
W34 & 44 & $0.17(0.05)$ & $0.22(0.03)$ & $-0.05(0.03)$ & $0.18(0.03)$ & 5.6 & 0.419 & 1.19 \\
W647 & 40 & $0.78(0.06)$ & $0.76(0.05)$ & $0.02(0.04)$ & $0.13(0.03)$ & 7.6 & 0.196 & 2.46 \\
V5895 & 55 & $0.17(0.05)$ & $0.13(0.01)$ & $0.03(0.06)$ & $0.21(0.05)$ & 4.7 & 0.421 & 1.18 \\
V6740 & 38 & $0.80(0.07)$ & $0.53(0.04)$ & $0.27(0.05)$ & $0.44(0.06)$ & 2.3 & 0.215 & 2.25 \\
V13196 & 56 & $0.12(0.04)$ & $0.11(0.01)$ & $0.02(0.03)$ & $0.25(0.06)$ & 4.0 & 0.442 & 1.13 \\
V13198 & 35 & $0.46(0.08)$ & $0.32(0.02)$ & $0.14(0.06)$ & $0.67(0.03)$ & 1.5 & 0.313 & 1.57 \\
V6791wf & 50 & $0.31(0.07)$ & $0.39(0.04)$ & $-0.08(0.04)$ & $0.15(0.02)$ & 6.6 & 0.360 & 1.38 \\
W1000 & 46 & $0.26(0.06)$ & $0.33(0.04)$ & $-0.07(0.04)$ & $0.17(0.03)$ & 6.0 & 0.379 & 1.31 \\
Amarillo MG-100 & 42 & $0.02(0.00)$ & $0.26(0.00)$ & $-0.24(0.00)$ & $0.10(0.00)$ & 9.9 & 0.492 & 1.02 \\
V13888 & 42 & $0.27(0.07)$ & $0.32(0.04)$ & $-0.05(0.04)$ & $0.19(0.05)$ & 5.2 & 0.376 & 1.32 \\
A. pintoi & 531 & $0.36(0.08)$ & $0.18(0.01)$ & $0.18(0.08)$ & $0.83(0.04)$ & 1.2 & 0.372 & 1.33 \\
\hline
\end{tabular}

- 0.86). The effective number of pollen donors $\left(N_{e p}\right)$ ranged from 1.2 to 9.9 among matrices with a general rate of 1.2.

The mean population and family coancestry coefficients $(\Theta)$ were higher (mean: 0.372; range: $0.196-0.492)$, and the effective size $\left(N_{e}\right)$ was lower (mean: 1.33; range: $1.02-2.46$ ) than what would be expected in panmictic populations $(\Theta$ $\left.=0.125 ; N_{e}=4\right)$.

\section{DISCUSSION}

The high frequency of heterozygous genotypes of $A$. pinto $i$ was higher than expected for an autogamous species. Observed heterozygosity was increased compared with expected heterozygosity, confirming the presence of high genetic diversity in matrices. The same unexpected heterozygous profile was observed for A. glabrata (Angelici et al. 2008). These authors already considered that cross-pollination could be significant. The high heterozigosity in our accessions resulted from the combination of different alleles that were conserved through vegetative propagation (Palmieri et al. 2010).

Our estimated outcrossing rate was greater than expected because Arachis was once generally accepted as autogamous by analogy to $A$. hypogaea. Our results corroborate previous reports of heterozygous profiles (Angelici et al. 2008; Palmieri et al. 2010). Our large sample size of 531 progenies allowed to infer more precisely the crossing rate.

The correlation of $t$ among families indicates high variation in outcrossing rate among matrices, which exhibited a predominance of mixed mating systems. However, some matrices were even close to allogamy ratios (V 6727, W 647 and V 6740). This variation directly interferes with the conservation of the germplasm collection, as the presence of pollinators may allow considerable gene flow and lead to loss of accession identity. As only matrices with sufficient seed production were genotyped for this study, our estimated outcrossing ratio for A. pinto $i$ is not representative of all accessions in the AGB of Embrapa Acre. The 12 matrices represent $8.6 \%$ of the AGB. Seed production is not a uniform trait among genotypes (Oliveira and Valls 2003). It also has to be considered that our estimated $t_{m}$ value reflects the reproductive performance of the accessions under the experimental conditions used in this study, including the presence of a set of undetermined pollinators and the specific climatic conditions in 2012/2013. It will thus be important to repeatedly evaluate the mating systems of the accessions in different environmental conditions and geographic locations. Characteristics of the pollen grain, as pore number, also modulate the outcrossing rate and will be analyzed in future studies.

Studies using molecular markers to estimate the mating system in wild species of Arachis have not been published. Outcrossing rates using morphological markers were estimated at $1.9 \%$ and $8 \%$ in $A$. hypogaea cultivars as described by Coffelt (1989) and Knauft et al. (1992). Our estimates obtained from molecular markers have detected higher values compared with morphological traits. Similarily, another leguminosae forage, Stylosanthes was described as autogamous based on morphological marker analyses (Bray and Hutton 1976). However, studies using microsatellites reported more accurate estimates (Santos-Garcia et al. 2011; Sousa et al. 2012; Ramos et al. 2019), as the analyses are based on many loci, detect high polymorphism in any growth stage, and can be applied in many progeny samples. Thus, our results support molecular genotyping as a more precise method to evaluate mating systems.

The values of $t_{s}$, which were generally lower than those of $t_{m}$, confirm the occurrence of crosses between relatives, which leads to biparental endogamy. These values were also influenced by the self-fertilization rate. The high value for paternity correlation $\left(r_{p(m)}\right)$ indicates that most offspring 
originated from outcrossing are full-sibs due to the low effective number of pollen donors (1.2) that fertilized the mother plants. The receptivity of the stigma and the pollen viability in $A$. pintoi may vary throughout the day (Flores $e t$ al. 2015), which, in addition to the late dehiscence of the anthers in some accessions (Knauft et al. 1992), may cause the low number of effective pollen donors.

The high coancestry coefficients $(\Theta)$ and low effective size $\left(N_{e}\right)$ were caused by the high selfing, the individual variation in the outcrossing rate, and the correlation of paternity. Frequency of identification, according to the descent alleles within progenies, and relatedness are increased by selfing and correlated with paternity (Sebbenn 2006; Spoladore et al. 2017).

Among the six forage-peanut cultivars included in the National Registry of Cultivars of the Brazilian Ministry of Agriculture, Livestock, and Food Supply (Registro Nacional de Cultivares do Ministério da Agricultura, Pecuária e Abastecimento - RNC-MAPA), Amarillo MG-100 is the most used commercially. Our $t_{m}$ estimate for this cultivar was $2 \%$, but only maternal alleles were identified in progeny genotyping. This very low crossing rate is very important to conserve the genotype identity. The features of floral biology, such as stigma surface and floral morphology, should be further investigated. Those traits could promote specific crosses between genotypes and generate genotypes with low crosses, which is desirable in an open field with pollinators present, as is the case in pastures.

\section{CONCLUSIONS}

Our analysis of the mating system in twenty accessions of forage peanut, Arachis pintoi, in an active germplasm bank in the southwestern Brazilian Amazon using genotyping with eight microsatellites, indicated the occurrence of a mixed mating system with a predominance of selfing, and that pollinators can influence $A$. pinto $i$ gene flow more than expected. We detected inbreeding and different levels of relatedness within families. Variable outcrossing rates among genotypes and the presence of pollinators could produce crosses and recombinant seeds inside parcels of the bank, so that further studies are required to assure the adequate conservation of accession identity.

\section{ACKNOWLEDGMENTS}

We are grateful to Unipasto, FUNTAC (TO: 008/2012) and to Embrapa for financial support. The first author is grateful to Coordenação de Aperfeiçoamento de Pessoal de Nível Superior (CAPES) for granting a Master's program scholarship.

\section{REFERENCES}

Angelici, C.M.L.C.D.; Hoshino, A.A.; Nóbile, P.M.; Palmieri, D.A.; Valls, J.F.M.; Gimenes, M.A.; Lopes, C.R. 2008. Genetic diversity in species of section Rhizomatosae, genus Arachis (Leguminosae), using microsatellite markers. Genetics and Molecular Biology, 31: 79-88.

Assis, G.M.L.; Krzyzanowski, F.C.; Azevedo, H.N. 2015. Superação de dormência em sementes de amendoim forrageiro cv. BRS Mandobi. (https://ainfo.cnptia.embrapa.br/digital/bitstream/ item/138837/1/25922.pdf). Accessed on 02/05/2018.

Assis, G.M.L.; Valentim, J.F.; Andrade, C.M.S. 2013. BRS Mandobi: a new forage peanut cultivar propagated by seeds for the tropics. Tropical Grasslands-Forrajes Tropicales, 1: 39-41.

Azêvedo, H.S.F.S.; Benvindo, F.D.; Cavalcante, L.N.; Haverroth, M.; Wadt, L.H.O.; Campos, T. 2017. Transferability of heterologous microsatellite loci between species of Euterpe genus. Genetics and Molecular Research, 16: 1-7.

Barcellos, A.D.O.; Ramos, A.K.B.; Vilela, L.; Junior, M.; Bueno, G. 2008. Sustentabilidade da produção animal baseada em pastagens consorciadas e no emprego de leguminosas exclusivas, na forma de banco de proteína, nos trópicos brasileiros. Revista Brasileira de Zootecnia, 37: 51-67.

Bray, R.; Hutton, E. 1976. Plant breeding and genetics. Tropical Pasture Research, 51: 353-388.

Campos, T.; Azêvedo, H.S.F.S.; Oliveira, J.C.; Ferreira Filho, J.A.; Yomura, R.B.T.; Silva, L.M. 2016. Protocolo para identificação de híbridos de amendoim forrageiro utilizando marcador molecular microssatélite. (https://ainfo.cnptia.embrapa.br/ digital/bitstream/item/156276/1/26263.pdf). Accessed on 14 May 2018.

Coffelt, T.A. 1989. Natural crossing of peanut in Virginia. Peanut Science, 16: 46-48.

Degen, B.; Sebbenn, A.M. 2014. Genetics and tropical forests. In: Pancel, L.; Köhl, M. (Ed.) Tropical Forestry Handbook. Springer Berlin Heidelberg, Berlin, p.1-30.

Dias Filho, M.B. 2011. Os desafios da produção animal em pastagens na fronteira agrícola brasileira. Revista Brasileira de Zootecnia, 40: 243-252.

Drumond, P.; Cardoso, G. 2010. As abelhas e a produção de sementes do amendoim forrageiro. (https://ainfo.cnptia.embrapa.br/ digital/bitstream/item/107463/1/abelhas-e-sementes.pdf). Accessed on 05 Aug 2018.

EMBRAPA, 2018. Balanço Social da Embrapa 2017. (http:// bs.sede.embrapa.br/2017/balancosocialembrapa2017print.pdf). Accessed on 25 Sep 2018.

Ferraz, J.B.S.; Felício, P.E. 2010. Production systems - An example from Brazil. Meat Science, 84: 238-243.

Flores, P.S.; Santos, V.B.; Silva, L.M.; Capistrano, M.C. 2015. Manual para teste de viabilidade e armazenamento de pólen e receptividade de estigma do amendoim forrageiro. (https://ainfo. cnptia.embrapa.br/digital/bitstream/item/137663/1/25892. pdf). Accessed on 02 Jul 2018.

Garcia, E.; Ramos Filho, F.S.V.; Mallmann, G.M.; Fonseca, F. 2017. Costs, benefits and challenges of sustainable livestock intensification in a major deforestation frontier in the Brazilian Amazon. Sustainability, 9: 1-17.

Gimenes, M.A.; Hoshino, A. A.; Barbosa, A.V.G.; Palmieri, D.A.; Lopes, C.R. 2007. Characterization and transferability of 
microsatellite markers of the cultivated peanut (Arachis hypogaea). BMC Plant Biology, 7: 9.

Goudet, J. 1995. FSTAT (version 1.2): a computer program to calculate F-statistics. Journal of Heredity, 86: 485-486.

Hardy, O.J.; Vekemans, X. 2002. SPAGeDI: a versatile computer program to analyze spatial genetic structure at the individual or population levels. Molecular Ecology Notes, 2: 618-620.

Hoshino, A.A.; Bravo, J. P.; Angelici, C.M.L.C.D.; Barbosa, A.V.G.; Lopes, C.R.; Gimenes, M.A. 2006. Heterologous microsatellite primer pairs informative for the whole genus Arachis. Genetics and Molecular Biology, 29: 665-675.

IBGE. 2017. Sistema IBGE de Recuperação Automática - SIDRA. (https://sidra.ibge.gov.br/tabela/3939). Accessed on $20 \mathrm{Nov}$ 2018.

Knauft, D.A.; Chiyembekeza, A.J.; Corbet, D.W. 1992. Possible reproductive factors contributing to outcrossing in peanut (Arachis hypogaea L.). Peanut Science, 19: 29-31.

Krapovickas, A.; Gregory, W. C. 2007. Taxonomy of the genus Arachis (Leguminosae). Bonplandia, 16 (Suppl.): 1-205.

Mazzetto, A.M.; Feigl, B.J.; Schils, R.L.M.; Cerri, C.E.P.; Cerri, C.C. 2015. Improved pasture and herd management to reduce greenhouse gas emissions from a Brazilian beef production system. Livestock Science, 175: 101-112.

Oliveira, M.A.P.; Valls, J.F.M. 2003. Morphological characterization and reproductive aspects in genetic variability studies of forage peanut. Scientia Agricola, 60: 299-304.

Palmieri, D.A.; Hoshino, A.A.; Bravo, J.P.; Lopes, C.R.; Gimenes, M.A. 2002. Isolation and characterization of microsatellite loci from the forage species Arachis pintoi (Genus Arachis). Molecular Ecology Notes, 2: 551-553.

Palmieri, D.A.; Bechara, M.D.; Curi, R.A.; Monteiro, J.P.; Valente, S.E.S.; Gimenes, M.A.; Lopes, C.R. 2010. Genetic diversity analysis in the section Caulorrhizae (genus Arachis) using microsatellite markers. Genetics and Molecular Biology, 33: 109-118.

Ramos, S.L.F.; Dequigiovanni, G.; Sebbenn, A.M.; Lopes, M.T.G.; Macedo, J.L.V.; Veasey, E.A.; Alves-Pereira, A.; Garcia, J.N.; Kageyama, P.Y. 2019. Mating system assessment of the Açaí-doAmazonas (Euterpe precatoria Mart.) using molecular markers. Crop Breeding and Applied Biotechnology, 19: 126-130.

Ritland, K. 2002. Estimation of gene frequency and heterozygosity from pooled samples. Molecular Ecology Notes, 2: 370-372.
Santos-Garcia, M.O.; Resende, R.M.S.; Chiari, L.; Zucchi, M.I.; Souza, P.S. 2011. Mating systems in tropical forages: Stylosanthes capitata Vog. and Stylosanthes guianensis (Aubl.) Sw. Euphytica, 178: 185-193.

Sebbenn, A.M. 2006. Sistema de reprodução em espécies arbóreas tropicais e suas implicaçôes para a seleção de árvores matrizes para reflorestamentos ambientais. In: Higa, A.R.; Silva, L. (Coord.). Pomares de Sementes de Espécies Forestais Nativas. FUPEF, Curitiba, p.193198.

Simeão, R.M.; Assis, G.M.L.; Montagner, D.B.; Ferreira, R.C.U. 2017. Forage peanut (Arachis spp.) genetic evaluation and selection. Grass and Forage Science, 72: 322-332.

Sousa, A.C.B.; Carvalho, M.A.; Campos, T.; Sforça, D.A.; Zucchi, M.I.; Jank, L.; Souza, A.P.; Souza, A.P. 2012. Molecular diversity, genetic structure and mating system of Calopogonium mucunoides Desv. Genetic Resources and Crop Evolution, 59: 1449-1464.

Spoladore, J.; Mansano, V.F.; Lemes, M.R.; Freitas, L.C.D.; Sebbenn, A.M. 2017. Genetic conservation of small populations of the endemic tree Swartzia glazioviana (Taub.) Glaz. (Leguminosae) in the Atlantic Forest. Conservation Genetics, 18: 1-13.

Tambarussi, E.V.; Boshier, D.; Vencovsky, R.; Freitas, M.L.M.; Sebbenn, A.M. 2015. Paternity analysis reveals significant isolation and near neighbor pollen dispersal in small Cariniana legalis Mart. Kuntze populations in the Brazilian Atlantic Forest. Ecology and Evolution, 5: 5588-5600.

Urbanski, A.S. 2016. Consórcio de pastagens como ferramenta para aumento de produtividade animal na Amazônia Ocidental. Master's dissertation, Universidade Federal do Acre, Brazil. 45p. (http://www.alice.cnptia.embrapa.br/alice/handle/ doc/1067249). Accessed on 18 Jun 2019.

Wadt, L.H.O.; Baldoni, A.B.; Silva, V.S.; Campos, T.; Martins, K.; Azevedo, V.C.R.; et al. 2015. Mating system variation among populations, individuals and within and among fruits in Bertholletia excelsa. Silvae Genetica, 64: 248-259.

Zu Ermgassen, E.K.; de Alcântara, M.P.; Balmford, A.; Barioni, L.; Neto, F.B.; Bettarello, M.M.; et al. 2018. Results from on-theground efforts to promote sustainable cattle ranching in the Brazilian Amazon. Sustainability, 10: 1-26.

\author{
RECEIVED: $17 / 01 / 2019$ \\ ACCEPTED: 05/06/2019 \\ ASSOCIATE EDITOR: Alexandre Pio Viana
}

